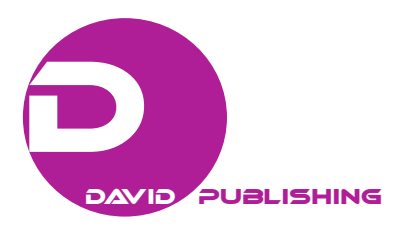

\title{
Family Involvement, Autonomy, and Social Competency in Homeschooling
}

\author{
María Ángeles Sotés-Elizalde, Carmen Urpí \\ University of Navarra, Pamplona, Spain
}

\begin{abstract}
Educational agents' demand on family involvement as a key to improve learning achievements raises home education model up to the top ranking of learning modalities, meanwhile, educational policies go to great pains to overcome school crisis. Family involvement affects children learning as much in the individual aspects as in the social participation into a world characterised by diversity. Consequently, a reflexive correspondence between individual diversity and social diversity is promoted for the improvement of personal development and social family context. In this way, family involvement and diversity are home-school keys to develop competencies; specially focussing on the autonomy and personal initiative competency and on the social and civic competency, which are included in the official curriculum of the educational system in Spain. Finally, we must emphasize the positive effects of service learning on the development of social competency of homeschoolers and the effects of technology on the development of autonomy.
\end{abstract}

Keywords: home education, parental engagement, family involvement, competency development, social and civic competency, social cooperation, service learning

\section{Introduction}

It seems natural and evident in the field of education that parents' concern and interest in their children's learning contributes toward better scholastic outcomes. In order to corroborate this, many studies have sought to obtain empirical evidence of this fact by studying the different influences that affect learning (Desforges \& Abouchaar, 2003).

Positive results from these studies have led in turn to the increasing use of programs that stimulate school-family cooperation, so that a greater number of children may receive the benefits. The general objective of such programs is greater possibilities for establishing collaborative strategies among all parties involved in the educational process: students, families, teachers, and school administrators (Bull, Brooking, \& Campbell, 2008).

The most successful programs are those that emphasize parental training, offered by the school, to prepare them in the use of specific support strategies for their children's learning (Robinson, Hohepa, \& Lloyd, 2009). Other programs emphasize training in more basic parenting competencies that affect children's general upbringing, such as social values and parental authority (Bernal, Urpí, Rivas, \& Repáraz, 2011).

María Ángeles Sotés-Elizalde, Ph.D., associate professor, School of Education and Psychology, University of Navarra. Carmen Urpí, Ph.D., associate professor, School of Education and Psychology, University of Navarra. 
But differences in parental involvement have been associated with socio-cultural level, with economically disadvantaged contexts and with parents' perceived role in their children's education and schooling (Glasgow \& Whitney, 2009). There is less involvement from families with disadvantaged socio-economic conditions, who belong to ethnic minorities, and who perceive themselves as disconnected from the schooling process of their children.

On the other hand, the schools that have had the most success in improving academic outcomes are those that manage to increase communication and to establish closer contact with families (Desforges \& Abouchaar, 2003). There is even greater improvement when the students themselves actively participate as members involved in these school-home cooperation programs (Brooking \& Roberts, 2007).

However, while the school institution seeks better academic performance from its students through family-involvement strategies, another educational modality is on the rise and focuses precisely on high parental involvement in their children's learning and education: homeschooling.

Research carried out in the United States (U.S.) regarding the academic outcomes of students who learn at home show the success of this educational modality through the high scores they obtain on state standardized tests, ${ }^{1}$ higher than the average scores of students enrolled in public and private schools (Isenberg, 2007). Rothermel (2012) pointed to other studies that find homeschoolers to be at least equal to and in some cases significantly better than their peers at school. In fact, numerous universities admit students who come from homeschooling (Bunday, 2013).

From this, we may infer a certain degree of educational competency in the parents; it would therefore be interesting for pedagogical research to look closely not only at the resources and teaching-learning strategies that are most used in homeschooling (Lines, 2001), but also at the teaching skills and educational competencies that parents develop in order to provide the necessary learning support to their children (Belando-Montoro, 2014; Sotés Elizalde, Urpí, \& Molinos Tejada, 2012).

In any case, we may affirm that education affects both the individual aspects of children's learning and their social participation in a diverse world, the latter requiring acquisition of competencies that form the basis for responsibility and lifelong learning.

\section{Competencies as a Basis for Responsibility and Lifelong Learning}

In recent years, the term "competencies" has been incorporated at all levels of educational systems; these encompass a combination of factors that, according to the Organization for Economic Co-operation and Development (OECD), require a favorable environment in order to be learned. The OECD, after a process of studying the values of different countries and cultures, has proposed a framework of key competencies, at the heart of which is "the ability of individuals to think for themselves and to take responsibility for their learning and for their actions" (OECD, 2005, p. 8).

For some time now, the European Union has associated key competencies with lifelong learning (Commission of the European Communities, 2005; 2006; 2008; European Parliament and Council of the European Union, 2006; Valle \& Manso, 2013), and in Spain, based on European recommendations, a set of basic competencies was established for compulsory education in Organic Law regarding education (Head of State, 2006). Each of these competencies has its own content, although they are related to each

\footnotetext{
${ }^{1}$ In this study, two groups of tests were administered according to the student's level: the Iowa Tests of Basic Skills (ITBS) and the Test of Achievement and Proficency, from Bob Jones University Press Testing and Evaluation Service.
} 
other. Basic competencies are those that "young people should have developed by the end of compulsory education in order to reach personal achievement, be an active citizen, join adult life and be able to develop permanent learning throughout life" (Ministry of Education and Science, 2006; 2007).

The current Organic Law for the improvement of educational quality (Head of State, 2013), which modifies the education law, expresses the following with regard to lifelong learning: Young people should be equipped with "basic competencies that are required in today's society, allowing them to put in practice the values that uphold democratic citizenship, common life and social cohesion, that stimulate their desire to continue learning and the ability to learn for themselves."

Although there are some signs of growing flexibility (Goiria, 2012; Goiria Montoya, 2014), we must keep in mind that homeschooling in Spain is not legally recognized for stages of compulsory education, thereby, excluding any standardized development of this modality. However, at the pedagogical level, the fact that there is a standardized curriculum does not mean that it cannot be learned in some other way, where curriculum competencies may be acquired outside of the school setting or more flexibly, combining school and other scenarios, such as is happening in other countries.

Specifically, we observe that learning has a two-fold content, individual and social; this is recognized within the curriculum of compulsory education through two basic competencies: the "autonomy and personal initiative competency" and the "social and civic competency." Both of these reflect the possibility of applying different types of knowledge in an interrelated manner, and not only accumulating them as compartments. In the next two sections, we discuss how development of these two competencies may be furthered in students whose education is based on homeschooling.

\section{The "Autonomy and Personal Initiative Competency" and Homeschooling}

Authors from educational theory stress that one of the aspirations of every human being is to be able to act autonomously and responsibly, in other words, to lead oneself toward a full life, using critical thought and being aware of what is best for one's life and for others.

Education seeks to offer the individual the needed conditions for achieving autonomy and it helps to practice behaviors and attitudes that reinforce that autonomy. Along with this, the educator helps learners reflect on their action, acquiring the understanding that is needed to prolong the individual's personal maturing process over time, by which progressively higher levels of practical consistency are attained (Altarejos \& Naval, 2004).

From the sphere of educational regulation, with basic competencies defined and selected through the OECD (2005), the recognition of autonomy as one of three large categories of competencies has ensured its inclusion in the educational legislation of different countries.

In Spain, regulations on curricular minimums for primary and secondary education include this competency under the name of "autonomy and personal initiative." According to Royal Decrees 1513/2006 and 1631/2006 (Ministry of Education and Science, 2006; 2007), which establish educational minimums for primary education and compulsory secondary education, respectively, the autonomy and personal initiative competency can be summarized as the ability to "imagine, undertake, develop, and evaluate individual or group actions and projects with creativity, confidence, responsibility, and critical thinking."

In both international and national contexts, the definition of this competency includes a social interpretation that goes beyond purely individual autonomy. The OECD document warns that: 
... Acting autonomously does not mean functioning in social isolation. On the contrary, it requires an awareness of one's environment, of social dynamics and of the roles one plays and wants to play. ... Individuals must act autonomously in order to participate effectively in the development of society and to function well in different spheres of life including the workplace, family life and social life. (OECD, 2005, p. 14)

The Spanish text also states that "this competency requires having social skills for relating to others, for cooperation and teamwork" (Ministry of Education and Science, 2006; 2007).

Given that the concept of competency corresponds to an educational approach based on lifelong learning, it may be stated that this competency is developed not only at school, but also through family life and through all social contexts that are involved in educating people as active citizens (Rychen \& Salganik, 2003).

In this sense, the possibilities that homeschooling offers for developing this competency have been demonstrated in certain empirical studies and in the evidence of scores obtained on standardized tests in some countries.

There are studies that assess this type of competency in homeschooling (Johnson, 1991; Brabant, 2010) through whether the student is able to finish the task by its due date, be responsible for organizing the own work schedule, self-assess what knowledge has been acquired, manage personal economy, or take charge of multiple household tasks. On the other hand, the primary parental competencies for helping the student acquire the autonomy and personal initiative competency include such strategies as drawing out and encouraging feelings of self-confidence and personal autonomy, or encouraging, allowing, and showing satisfaction and confidence toward behaviors that show autonomy or decision-making (Johnson, 1991).

It is a fact that, in countries where homeschooling is regulated as a valid educational modality, universities that admit homeschooled students report a positive estimation of their autonomy and personal initiative competency. This would lead us to understand that, contrary to criticisms that homeschooling parents are overprotective, development of the autonomy and personal initiative competency for one's own learning is encouraged when the student enjoys the parents' support and involvement. At the same time, while we may infer that more personalized educational attention is not necessarily accompanied by the student's excessive dependency on the teaching figure, it seems reasonable to think that good academic outcomes are supported by the above-mentioned attitudinal competencies in the student, as well as the corresponding teaching competencies in the educators.

Having said that, we make no claims that homeschooling is a more valid educational modality in overall terms than schooling at a public or private school. In reality, differences between the teaching-learning process of the two situations/environments — school and family home — are so great that it is difficult to make comparative measurements between them (Sotés Elizalde et al., 2012). However, we gather from observation and analysis of the teaching-learning style that is pursued in these homes, that the autonomy and personal initiative competency is being developed positively, that it supports the academic outcomes that are achieved, and the social and civic competency is developed within a favorable family environment that is integrated in a community—an aspect that we address in the next section.

\section{Social Participation for a Diverse World, the Social and Civic Competency and Homeschooling}

With regard to the social dimension of human beings, authors from educational theory state that we 
are cultural beings who transform our responses and behavior into valid elements for relating to our surroundings, to others, and to ourselves (García Aretio, Ruiz Corbella, \& García Blanco, 2010). This was not invented by the school, in any case school has contributed to a certain manner of enculturation along these lines, especially in the last two centuries when national educational systems have been developed and civic education has been a means of inculcating constitutional principles and of establishing the political principles of states (Ossembach Sauter, 2011; Sotés Elizalde, 2009).

In today's world, school has become a context for socialization and transmission of values through curriculum content, whether cross-curricular or subjects specific (Bárcena, Gil, \& Jover, 2009). But in the information society in which we live, school shares its teaching capacity more and more with elements of society, whether unintentionally or in organized fashion, through joint, cooperative programs with activities oriented toward greater involvement in our diverse cultural context (Segovia Aguilar, 2011). According to Brabant $(2006 ; 2010)$, there are different perspectives when it comes to participation and civic education, both within the school and in homeschooling.

In Spain's educational system, curriculum competencies related to social participation revolve particularly around the "social and civic competency" established as a basic competency in Organic Law legislation for primary and compulsory secondary education, being thus defined:

5. SOCIAL AND CIVIC COMPETENCY. This competency makes it possible to understand the social reality in which one lives, to cooperate, coexist and exercise democratic citizenship in a plural society, as well as become involved in its betterment. Integrated within this competency is a variety of knowledge and complex skills that enable one to participate, make decisions, choose how to behave in determined situations and be responsible for choices and decisions adopted. ... Overall, in order to function socially, the individual must make use of knowledge about the evolution and organization of societies and about the traits and values of the democratic system, as well as use of moral judgment for making choices and decisions, and for actively, responsibly exercising the rights and duties of citizens. (Ministry of Education and Science, 2006; 2007)

This generic definition entails a number of possibilities related to such social participation, and one needs only to read the legislation regarding this competency in compulsory education to infer that there are many different activities that lead to its acquisition.

Based on the foregoing, then, we ask: What elements of homeschooling show that it prepares the individual for responsible social participation? First, outside of the purely curricular question, it may be noted that many homeschooling families create or maintain associations (Cabo González, 2012; Orozco Jabato, Mc Inerney, \& Pérez Rodríguez, 2011). Then, they exercise the right to freedom of association, one of the exponents of democratic participation when this is understood as something more than merely exercising the right to vote.

On the other hand, according to certain international studies, most homeschooled students combine learning at home with extracurricular activities where they relate to a variety of children and families and participate in community and volunteer activities (Medlin, 2000; Ray, 2000). These studies confirm that they attend formal and informal academic events related to art, sciences, ecology, literature, and other events organized by universities, schools, and entities open to the general public (Connecticut Homeschool Network, Inc. [CHN], 2012; Walters, 2015).

There is yet another form of social participation that contributes to development of the social and civic competency, which in our estimation is underutilized both at school and in homeschooling. This 
consists of exploiting the service learning methodology to attain some benefit for the community. This is a form of civic education that translates into real contributions, made in the form of projects where students themselves participate in their configuration, development, and evaluation (Martínez-Odría, 2007a), while at the same time, developing the autonomy and personal initiative competency.

Service learning has certain defining characteristics in the school context, even though they do not always take shape in the same way or with the same intensity. These characteristics are as follows (Martínez-Odría, 2007b):

1. Detecting real needs in the community and act on them;

2. Opening educational institutions to their social environment;

3. Encouraging coordination among educational institutions, social organizations, and other elements of the community;

4. Placing special emphasis on curriculum content and working within areas that are structured under the curriculum;

5. Following a type of pedagogy based on experience, active participation, interdisciplinarity, teamwork, and the indispensable role of reflection.

If civic responsibility is linked to a citizen's engagement with the community, service learning may be cited as a factor that promotes civic responsibility in students. From this basis then, we understand this methodology to be adaptable and applicable to homeschooling, since families may adopt these principles in relation to social participation and apply them within their own content.

While it is true that most service learning programs have been carried out through school channels, the possibilities for homeschooling easily come to mind, if we consider the wide-ranging associativism that is linked with these families, through which they engage in service to their community. For these reasons, from an open-minded conception of homeschooling, not as a marginal variant of school, but as another recognized option within the educational system, one might consider the possibility of involving these families in service learning programs or other programs sponsored by local entities or non-profit organizations (local governments, associations, or foundations). This might even be accomplished through the schools, assuming that they are sufficiently flexible and open to accepting the participation of these families in their programs. The idea of flexible schooling encourages better understanding of and visibility for the homeschooling modality.

\section{Scholastic Flexibilization and the Introduction of Information and Communications Technologies (ICTs)}

The introduction of ICTs into the world of education is of particular interest to these families who choose to have "school at home," both for learning and for their participation in the educational community (Marsh, Carr-Chellman \& Sockman, 2009; Walters, 2015). ICTs, and especially the growing use of communication networks, may encourage these families' interaction with the administrators of their corresponding schools, parent-teacher associations, local institutions, and civil society organizations, such that these pupils may be included as members of the educational community and actively participate in global citizenship.

Along these lines, continuing from Gros and Contreras (2006), Aznar Minguet (2007) analyzed the possibilities of ICTs in the development of civic competencies. Although this author did not explicitly 
refer to the modality of homeschooling, her conclusions were quite suggestive when we think of learning on the network as a key strategy for many homeschoolers:

Use of the new communication networks for promoting civic values, through development of civic competencies, would need to be founded on a concept of networked learning through interactive processes of participation in cultural practices and in activities shared by social communities or civil society organizations. (Aznar Minguet, 2007, p. 347)

The educational resources that technological advancement has made available, not only to schools but also to the student and the family, open up a wide horizon of more flexible pedagogical possibilities that are adaptable to every particular case. On one hand, there are virtual classrooms sponsored by private or public initiative in the non-formal sphere (academies, museums, libraries, and other institutions), and on the other hand, there are virtual classrooms sponsored by the schools themselves in order to support or increase knowledge. There is no great leap from these two realities to the cyber charter schools of the U.S., or virtual schools in the U.K.. The near future promises an abundance of mixed educational possibilities that combine face-to-face and distance education, formal and non-formal education, where individual needs may be met and there is attention to the diversity of students and their socio-family context (Editorial Projects in Education, 2012).

\section{Conclusion}

Educational systems in different nations, under the guidance of international recommendations, have various resources to ensure that each person's potentialities are developed, both at the individual and social levels. Schools, as the main channel for the established curriculum to produce such a development, have placed the emphasis in recent years on competencies that must be attained by students as they pass through.

But, in addition to the school channel, generally very structured and programmed, and prepared to serve a certain number of students typically stipulated by law, there is another modality in use, recognized in many countries, where teaching usually takes place in the family home or through other means, and measurable results are obtained, compatible with standards established for learning at school.

After discussing two basic competencies that are more directly related to students' individual and social elements, namely, the "autonomy and personal initiative competency" and the "social and civic competency," we may conclude that both can be attained through either traditional school or homeschooling.

There are procedures, content, and activities that, being approached for common objectives, are able to develop the two types of competencies, since it is possible to work autonomously in pursuing social project initiatives, with community or civic participation purposes.

The present study has examined pedagogical aspects more than legal, historical, or country-comparison issues, which have been addressed in other contexts. In short, the teaching-learning process is a universal question that in and of itself allows for many variations regardless of the situation at each moment, even though the issues mentioned above affect this process greatly.

In the knowledge society, where many borders are becoming increasingly blurred, learning must not only be guaranteed for the whole population with no exception, but at the same time, be considered in all its breadth and diversity. Homeschooling has proven to be one of those possibilities for consideration, as 
long as it enables the acquisition of the competencies that at any given moment in history are considered to be key for the individual and social development of persons.

\section{References}

Altarejos, F., \& Naval, C. (2004). Filosofía de la educación (Philosophy of education) (2nd ed.). Pamplona: Eunsa.

Aznar Minguet, P. (2007). Familia, sociedad y redes de comunicación (Family, society and communication network). Bordón, 59(2-3), 335-352.

Bárcena, F., Gil, F., \& Jover, G. (2009). La escuela de ciudadanía: Educación, ética y política (A school for citizenship: Education, ethics and politics). Bilbao: Descleé de Brouwer.

Belando-Montoro, M. R. (2014). Diversidad de intereses y necesidades de aprendizaje en una sociedad compleja y cambiante: la educación en el hogar como posibilidad (A diversity of interests and learning needs in a complex and changeable society). In I. M. Briones Martínez (Coord.), Educación en familia: Ampliando derechos educativos y de conciencia (Familiy education: Extending the right to education and the rights of conscience) (pp. 313-320). Madrid: Dykinson.

Bernal, A., Urpí, C., Rivas, C., \& Repáraz, Ch. (2011). Social values and authority in education: Collaboration between school and family. International Journal About Parents in Education, 5(2), 134-143.

Brabant, C. (2006, September). Citizenship education: A collaborative research with home educators. Paper presented at The European Conference on Educational Research Post Graduate and New Researcher Pre-Conference, University of Geneva. Retrieved May 14, 2015, from http://www.leeds.ac.uk/educol/documents/165018.htm

Brabant, C. (2010). Pour une gouvernance réflexive de l'«apprentissage en famille». Étude des processus d'apprentissage de trois groupes de parents-éducateurs au Québec (For a reflexive governance of homeschooling. A study of the learning procedure in three groups of parent-educators in Quebec) (Doctoral dissertation, Faculté d'Education, Université de Sherbrooke, Québec).

Brabant, C. (2013). L'école à la maison au Québec: Un projet familial, social et démocratique (Homeschooling in Quebec: A family, social and democratic project). Quebec: Presses de l'Université du Québec.

Brooking, K., \& Roberts, J. (2007). Evaluation of the home-school partnership: Literacy programme (Report to the Ministry of Education by NZCER). Wellington: Ministry of Education. Retrieved March 17, 2014, from http://www.educationcounts.govt.nz/publications/curriculum/evaluation_homeschool

Bull, A., Brooking, K., \& Campbell, R. (2008, June). Successful home-school partnerships. Wellington: Ministry of Education. Retrieved March 18, 2014, from http://www.educationcounts.govt.nz/publications

Bunday, K. M. (2013). Colleges that admit homeschoolers. Retrieved June 3, 2014, from http://learninfreedom.org/ colleges_4_hmsc.html

Cabo González, C. (2012). El Homeschooling en España: Descripción y análisis del fenómeno (Homeschooling in Spain: A description and analysis of the phenomenon) (Doctoral dissertation, Departamento de Ciencias de la Educación, Universidad de Oviedo). Retrieved June 21, 2015, from http://encina.pntic.mec.es/jcac0007/indice.htm

Commission of the European Communities. (2005). Commission staff working document: Towards a European qualifications framework for lifelong learning. Brussels: European Commission.

Commission of the European Communities. (2006). Implementing the community Lisbon programme-Proposal for a recommendation of the European Parliament and of the council on the establishment of the European qualifications framework for lifelong learning (COM(2006)479; SEC(2006)1093; SEC(2006)1094). Brussels: European Commission.

Commission of the European Communities. (2008). Communication from the Commission to the European Parliament, the Council, the European Economic and Social Committee, and the Committee of the Regions-Improving competences for the 21st century: An agenda for European cooperation on schools. Brussels: European Commission.

Connecticut Homeschool Network, Inc.. (CHN). (2012). Calendar of events. Retrieved June 19, 2012, from http://www.cthomeschoolnetwork.org/CalendarListings.asp

Desforges, C., \& Abouchaar, A. (2003). The impact of parental involvement, parental support and family education on pupil achievements and adjustment: A literature review. Retrieved June 18, 2014, from http://www.bgfl.org/bgfl/cust om/files_uploaded/uploaded_resources/18617/Desforges.pdf

Editorial Projects in Education. (2012, March 7). Accelerating innovation (A special report on K-12 innovation and the business of education). Education Week Supplement, 23(31). 
European Parliament and Council of the European Union. (2006). Recommendation 2006/962/EC of the European Parliament and of the Council of 18 December 2006 on key competences for lifelong learning. Official Journal of the European Union, L394/10. Luxembourg: Publications Office of the European Union.

García Aretio, L., Ruiz Corbella, M., \& García Blanco, M. (2010). Claves para la educación: Actores, agentes y escenarios en la sociedad actual (Educational keys: Actors, agents and settings from todays' society). Madrid: Narcea-UNED.

Glasgow, N. A., \& Whitney, P. J. (2009). What successful schools do to involve families: 55 partnership strategies. Thousand Oaks, C.A.: Corwin Press.

Goiria Montoya, M. (2014). La opción de educar en casa. Implantación social y encaje en el homeschool en el ordenamiento jurídico español (The option of educating at home. The homeschooling social implementation and adaptation into Spanish judicial framework). Valencia: Tirant Monografías.

Goiria, M. (2012). La flexibilización educativa o lo mejor de dos mundos: Entre la escolarización y el homeschool (The flexible education or the best of two worlds: In-between schooling and homeschooling). Estudios sobre Educación, 22(Junio), 37-54.

Gros, B., \& Contreras, D. (2006). La alfabetización digital y el desarrollo de competencias ciudadanas (Digital literacy and development of citizenship skills). Revista Iberoamericana de Educación, 42, 103-125.

Head of State. (2006). Ley Orgánica 2/2006, de 3 de mayo, de Educación (Organic Law 2/2006 of 3 May, of education). Retrieved from https://www.boe.es/buscar/act.php?id=BOE-A-2006-7899

Head of State. (2013). Ley Orgánica 8/2013, de 9 de diciembre, para la mejora de la calidad educative (Organic Law 8/2013, of December 9, to improve educational quality). Retrieved from http://www.boe.es/diario_boe/ txt.php?id=BOE-A-2013-12886

Isenberg, E. J. (2007). What have we learned about homeschooling. Peabody Journal of Education, 82(2-3), 387-409.

Johnson, K. C. (1991). Socialization practices of Christian home school educators in the State of Virginia (Doctoral dissertation, Curry School of Education, University of Virginia). Retrieved February 16, 2015, from $\mathrm{http} / / /$ digitalcommons.liberty.edu/cgi/viewcontent.cgi?article=1032\&context=fac_dis

Lines, P. (2001, September). Homeschooling. ERIC Digest, 151. Retrieved October 14, 2013, from http://www.discovery. org/a/1068

Marsh, R. M., Carr-Chellman, A. A., \& Sockman, B. R. (2009). Why parents choose cyber charter schools. TechTrends, 53(4), 32-36.

Martínez-Odría, A. (2007a). Service-learning o aprendizaje-servicio: La apertura de la escuela a la comunidad local como propuesta de educación para la ciudadanía (Service-learning: The school's openness to local community as a proposal for citizenship education). Bordón, 59(4), 627-640.

Martínez-Odría, A. (2007b). La nueva ciudadanía que surge de la cooperación entre instituciones educativas y comunidad. Las posibilidades del service learning (New citizenship emerging from the cooperation between educational institutions and community). In Civicus, Service learning o aprendizaje-servicio: Diálogo entre la universidad y la comunidad: Una guía práctica (Service learning: A dialogue between university and community: A practical guide) (pp. 13-59). Fundación General: Universidad de Valladolid.

Medlin, R. G. (2000). Home schooling and the question of socialization. Peabody Journal of Education, 75(1-2), 107-123.

Ministry of Education and Science. (2006). Real Decreto 1513/2006, de 7 de diciembre, por el que se establecen las enseñanzas mínimas de la educación primaria (Royal Decree 1513/2006, of 7 December, establishing the core curriculum of primary education). Retrieved from https://www.boe.es/buscar/doc.php?id=BOE-A-2006-21409

Ministry of Education and Science. (2007). Real Decreto 1631/2006, de 29 de diciembre, por el que se establecen las enseñanzas mínimas correspondientes a la educación secundaria obligatoria (Royal Decree 1631/2006 of 29 December, the core curricula compulsory secondary education are established). Retrieved from http://www.boe.es/diario_boe/txt.php?id=BOE-A-2007-238

Organization for Economic Co-operation and Development (OECD). (2005). The definition and selection of key competencies executive summary. Retrieved July 22, 2014, from http://www.oecd.org/pisa/35070367.pdf

Orozco Jabato, F., Mc Inerney, D., \& Pérez Rodríguez, A. (2011, November). Asociarse para defender el derecho a aprender en familia. (Asociación para la Libre Educación, ALE) (Partnership to defend the right to learn in family) (Association for Free Education). Paper presented at The II Congreso Nacional y I Internacional Sobre Educación en Familia-Homeschooling. Innovación Educativa, TIC y Escuela Flexible, University of Navarra. Retrieved from http://aleenred.blogspot.com.es/2011/12/ponencia-de-ale-en-el-ii-congreso.html 
Ossembach Sauter, G. (2011). Génesis de los sistemas educativos nacionales (The genesis of national educational systems). In G. Ossembah Sauter (Coord.), Corrientes e instituciones educativas contemporáneas (Contemporary educational institutions and movements) (pp. 21-39). Madrid: Universidad Nacional de Educación a Distancia.

Ray, B. D. (2000). Home schooling for individuals' gain and society's common good. Peabody Journal of Education, 75(1-2), 272-293.

Robinson, V., Hohepa, M., \& Lloyd, C. (2009). School leadership and student outcomes: Identifying what works and why-Best evidence synthesis iteration (BES). New Zealand: Ministry of Education. Retrieved July 24, 2015, from https://www.educationcounts.govt.nz/_data/assets/pdf_file/0015/60180/BES-Leadership-Web-updated-foreword-2015.pdf

Rothermel, P. J. (2012). Home educated children's psychological well being. Estudios sobre Educación, 22(Junio), 13-36.

Rychen, D. S., \& Salganik, L. H. (2003). Key competencies for a successful life and a well-functioning society. Hogrefe \& Huber.

Segovia Aguilar, B. (2011). Educación comunitaria y nuevas alfabetizaciones (Communitarian education and new literacies). In R. Aparici (Coord.), Conectados en el ciberespacio (Connected to the cyberspace) (pp. 217-234). Madrid: Universidad Nacional de Educación a Distancia.

Sotés Elizalde, M. Á. (2009). Catecismos políticos e instrucción política y moral de los ciudadanos (Siglos XVIII y XIX) (Political catechisms and political and moral instruction of citizens in the XVIII and XIX centuries in France and Spain). Educación, XX1(12), 201-218.

Sotés Elizalde, M. Á., Urpí, C., \& Molinos Tejada, M. C. (2012). Diversidad, participación y calidad educativas: necesidades y posibilidades del homeschooling (Diversity, parent involvement and quality education: Needs and possibilities of homeschooling). Estudios Sobre Educación, 22(Junio), 55-72.

Valle, J., \& Manso, J. (2013). Competencias clave como tendencia de la política educativa supranacional de la Unión Europea (Key competencies as a trend in the EU's supranational educational policy). Revista de Educación (Extraordinario), 12-33.

Walters, L. A. (2015). Relationships of parental homeschooling approaches including technology integration. Retrieved August 20, 2015, from http://aquila.usm.edu/cgi/viewcontent.cgi?article=1102\&context=dissertations 